natureresearch

Check for updates

\title{
OPEN Publisher Correction: Sharing of hand kinematic synergies across subjects in daily living activities
}

\author{
Verónica Gracia-Ibáñez ${ }^{\circledR}$, Joaquín L. Sancho-Bru ${ }^{\circledR}$, Margarita Vergara $\mathbb{B}^{\circledR}$, \\ Néstor J. Jarque-Bou 10 \& Alba Roda-Sales $『$
}

Correction to: Scientific Reports https://doi.org/10.1038/s41598-020-63092-7, published online 09 April 2020

The Article contains errors in Table 2 where some table headings were not marked as headings. The correct Table 2 appears below.

\begin{tabular}{|c|c|c|c|c|c|c|c|c|}
\hline \multirow{2}{*}{$\begin{array}{l}\text { Digit } \\
\text { Joints }\end{array}$} & \multicolumn{4}{|l|}{1} & $2-3$ & $3-4$ & $4-5$ & \multirow[b]{2}{*}{ Palmar Arch } \\
\hline & CMC A & CMC F & MCP F & IP F & \multicolumn{3}{|c|}{ MCP A } & \\
\hline Mean & 7.8 & 8.0 & 2.6 & 18.8 & 7.3 & 4.9 & 5.4 & 41.1 \\
\hline SD & 16.9 & 48.3 & 33.3 & $\begin{array}{l}79.4 \\
\end{array}$ & 39.5 & 29.5 & 32.5 & 69.1 \\
\hline Digit & 2 & 3 & 4 & 5 & 2 & 3 & 4 & 5 \\
\hline Joints & \multicolumn{4}{|l|}{ MCP F } & \multicolumn{4}{|c|}{ PIP F } \\
\hline Mean & 22.7 & 27.0 & 25.3 & 23.3 & 52.5 & 45.0 & 46.5 & 41.1 \\
\hline SD & 67.8 & \begin{tabular}{|l|}
77.6 \\
\end{tabular} & \begin{tabular}{|l|}
68.4 \\
\end{tabular} & \begin{tabular}{|l|}
63.9 \\
\end{tabular} & \begin{tabular}{|l|}
79.6 \\
\end{tabular} & \begin{tabular}{|l|}
73.0 \\
\end{tabular} & \begin{tabular}{|l|}
79.7 \\
\end{tabular} & 69.1 \\
\hline
\end{tabular}

Table 2. Mean and SD values per joint to apply the non-standard scaling. Digits 1 to 5 mean thumb to little digit. $\mathrm{F}$ for flexion, A for abduction.

\begin{abstract}
(c) (1) Open Access This article is licensed under a Creative Commons Attribution 4.0 International License, which permits use, sharing, adaptation, distribution and reproduction in any medium or format, as long as you give appropriate credit to the original author(s) and the source, provide a link to the Creative Commons license, and indicate if changes were made. The images or other third party material in this article are included in the article's Creative Commons license, unless indicated otherwise in a credit line to the material. If material is not included in the article's Creative Commons license and your intended use is not permitted by statutory regulation or exceeds the permitted use, you will need to obtain permission directly from the copyright holder. To view a copy of this license, visit http://creativecommons.org/licenses/by/4.0/.
\end{abstract}

(C) The Author(s) 2020 